\title{
Yttrium Y 90 Anti-CD45 Monoclonal Antibody AHN-12
}

National Cancer Institute

\section{Source}

National Cancer Institute. Yttrium Y 90 Anti-CD45 Monoclonal Antibody AHN-12. NCI

Thesaurus. Code C74093.

A radioimmunoconjug ate comprised of the monoclonal antibody $\mathrm{AHN}-12$ conjug ated to the radioisotope yttrium 90 with potential radioimmunotherapeutic activity. Yttrium Y 90 monoclonal antibody AHN-12 binds to the tyrosine phosphatase CD45, expressed on the surface of normal and malignant hematopoietic cells. After binding and internalization by CD45-expressing tumor cells, this agent may deliver a cytotoxic dose of beta radiation. 